\title{
Phenotypic Characterization of Naturalized Swine Breeds in Brazil, Uruguay and Colombia
}

\author{
Concepta McManus ${ }^{1 *}$, Samuel Rezende Paiva ${ }^{2}$, Alva Vanessa Rezende Silva ${ }^{1}$, Luci Sayori \\ Murata $^{1}$, Helder Louvandini ${ }^{1}$, Glória Patrícia Barrera Cubillos ${ }^{3}$, Gustavo Castro ${ }^{4}$, Rodrigo \\ Alfredo Martinez ${ }^{3}$, Maria Sílvia Llambi Dellacasa ${ }^{4}$ and Juan Esteban Perez ${ }^{3}$ \\ ${ }^{1}$ Faculdade de Agronomia e Medicina Veterinária; Universidade de Brasília; 70910-900; Brasília - DF - Brasil. \\ ${ }^{2}$ Embrapa Recursos Genéticos e Biotecnologia; Final W5 Norte; 70771-900, Brasília - DF - Brasil. ${ }^{3}$ Corporación \\ Colombiana de Investigación Agropecuária; Km. 14, Vía Mosquera; Bogotá - Colômbia. ${ }^{4}$ Luis A. de Herrera \\ 1503/1003; CP 11.600; Montevideo - Uruguay
}

\begin{abstract}
Morphometric data was collected on 859 naturalized swine in Brazil (Piau, Tatu, Nilo, Caruncho, Casco de Burro, Moura, Monteiro and Rabo de Peixe), Colombia (Criolla Zungo, Sanpedreño and Casco de Mula) and Uruguay (Mamellado), both on farm and in published material. Information was collected on breed, sex and age, as well as various morphometric measurements. Analysis of variance was carried out using PROC MIXED of SAS ${ }^{\circ}$ on phenotypic data. The coefficients of variance varied between 11.50 and $83.81 \%$, and the coefficient of determination was medium to high. Females were in general smaller for most measurements than males, showing sexual dimorphism. The Moura was the closest naturalized breed to the commercial breeds, followed by the Piau, while the Monteiro was the furtherest. The dendrogram obtained from morphological information showed a division of the pigs into three groups. Characterization was possible using morphological and morphometric data.
\end{abstract}

Key words: Measures, morphology, morphometric, phenotypic distance

\section{INTRODUCTION}

Naturalized swine breeds found in Brazil and other Latin American countries, also known as crioula breeds, are originated from those brought by the Portuguese and Spanish settlers during the $16^{\text {th }}$ century. According to Mariante and Cavalcante (2000), these breeds underwent natural selection to acquire adaptive traits in specific local environments over time. Some naturalized breeds, although they have different names in different regions, are phenotypically similar. This leads to doubts about their identity as a distinct racial group. These populations may be genetically similar or have accumulated differences due to geographic isolation and adaptation to specific geographic niches (Mariante and Egito, 2002). The lack of data recording and specification of traits, large distances between farms and the small size of the breeding population in naturalized swine herds makes it difficult to effectively work with them (Garcia and Barbosa, 2005). Some nuclei were kept by breeders and researchers between the

*Autor for correspondence: concepta@unb.br 
1930s and 1970s for study and selection, but at present little is known about the geographic distribution, representativity, economic importance and production of naturalized swine breeds. Crossbreeding and selection can rapidly modify characteristics of a breed, giving rise to different genetic groups, complicating breed identification. Although molecular techniques have aided in the identification and characterization of individuals and breeds, phenotypic and production characterization is also necessary. Therefore, the use of breed standardization, definition of unique traits and determination of risk to which a breed is subjected is useful to better know the breeds in question (Rothschild, 2003). The conservation and improvement of naturalized breeds is justified as they may contain a pool of genetic material for maintenance and improvement of specific traits in the commercial population, especially in terms of heat and parasite resistance (Notter, 1998). Egito et al. (2002) noted that the in depth study of breeds may facilitate the development and rational control of future breeding programs, as well as the preservation and conservation of germplasm. The systematic understanding of pig breeding implies that knowledge of the historical basis which gives foundation to the origin and evolution of breeds is necessary. The similarity and differences between commercial and native breeds is important to identify and evaluate their origins and possible sources of genes for genetic improvement of herds. Animal size is also necessary to determine feeding regimes and housing requirements (Anil et al., 2002). Space allocation is one also an important variable for farm animals and has a direct affect on the welfare of farm livestock (Pastorelli et al., 2006). Insufficient space allocation for pigs in confinement has been shown to affect growth and productive performance, and may affect animal health (Gonyou and Stricklin, 1998; Spoolder et al., 2000). Body measurements are also used to determine weight when no weighing scales are available, which is frequently the case with naturalized breeds (Lawrence and Fowler, 1997). Few studies have been carried out on the diversity of naturalized swine breeds in South American countries. Subjective data is frequently missing for most naturalized breeds of farm animals (FAO, 1999). Knowledge about the genetic, morphological and productive characteristics of the breed as well as about its products is essential in order to set up a rational production system (Pietrolà et al., 2006). This study aimed to phenotypically characterize naturalized swine breeds in Brazil, Uruguay and Colombia and compare breed distances using morphometic and size data.

\section{MATERIALS AND METHODS}

Data was collected on 859 (59\% female and $41 \%$ male) naturalized adult pigs in Brazil, Uruguay and Colombia. Data was also available from literature. The Brazilian breeds studied were Piau, Tatu, Nilo, Caruncho, Casco de Burro (Mulefoot), Moura, Monteiro and Rabo de Peixe (Fishtail). From Colombia data was available on the Criolla Zungo, Sanpedreño and Casco de Mula breeds, while the Mamellado breed was studied in Uruguay. Commercial herds included in this study were Landrace, Large White, Yorkshire and Duroc. The herds were selected due to their population size, breed purity and lack of inbreeding between herds to obtain a representative sample of the breeds. In Brazil, data were collected in Minas Gerais, Santa Catarina, Mato Grosso do Sul and Bahia states as well as the Federal District. Data from Colombia and Uruguay were collected near Bogotá and Montevideo, respectively. Data collection was standardized in meetings held at the beginning of the experiment. Since data were collected by different people in the three countries there may be an effect of technician but this was not included in the model as it was confounded with country. Phenotypic characterization included information on breed, sex, age, body length (BL), dorso-sternal distance (DD), ear length (EL), head length (HL), heart girth (HG), interisquiatic distance (DI), interorbital distance (ID), length of hip (LH), longitudinal distance (LD), shoulder height (SH), shoulder length (SL), snout length (SL), tail length (TL). All animals were measured standing symmetrically on a flat solid surface. Definitions and anatomical localization of these can be seen in Table 1. Breeds were classified according to the following traits: Head shape: concave, subconvex or rectilinear; ear shape: Asiatic, Iberian or Celtic; Back line: straight, concave or convex; Abdomen: straight or pendulous; Skin colour: black, red or white; Hair: without or with (straight/curly, long/short, soft/hard); coat colors: olive, spotted, red, black, white or speckled; Tail: curly, straight, fish tail; Temperament: aggressive or docile. 
Phenotypic data were analysed using simple descriptive measures (mean, standard deviation) and meta-analysis using PROC MIXED of SAS (1999). Distances between breeds were carried out using morphology and measurements by sex, calculating dissimilarity and distance using
UPGMA (Unweighted Pair Group Method Arithmetic Mean) to generate the dendrogram. Only adult animals were considered. The statistical analysis programs GENES ${ }^{\circledR}$ and STATISTICA $®$ were used to evaluate population structure.

Table 1 - Traits of morphological measurements realized with naturalized and commercial swine breeds in Brazil, Colombia and Uruguay.

\begin{tabular}{|c|c|}
\hline Trait & Description \\
\hline Body length (BL) & $\begin{array}{l}\text { Distance from the external occipital protuberance to the base of the tail on the } \\
\text { dorsal line; distance between tip of scapula and ischium, measured as the distance } \\
\text { between the point of shoulder and the pin bone. }\end{array}$ \\
\hline Dorso-sternal distance (DD) & From the point of the shoulder to the sternum; distance between dorso and sternum \\
\hline Eye distance (ED) & Inter orbital distance \\
\hline Ear length (EL) & $\begin{array}{l}\text { From central point of the base to the vertix; from the base of the notch to the most } \\
\text { distant point of the margin of the pinna (external ear) }\end{array}$ \\
\hline Head length (HL) & From the external occipital protuberance occipital to tip of nasal bone \\
\hline Heart girth $(\mathrm{HG})$ & $\begin{array}{l}\text { Total distance around the animal (circumference) measured directly behind the } \\
\text { front leg; total distance around the animal (circumference) measured directly } \\
\text { behind the front leg; }\end{array}$ \\
\hline Interisquiatic distance (DI) & Distance between external point of both isquial bones \\
\hline Interorbital distance (ID) & $\begin{array}{l}\text { Between both frontal sigmoid apophysis; distance between left and right } \\
\text { endocanthion; }\end{array}$ \\
\hline Length of hip (LH) & $\begin{array}{l}\text { From the external iliac tuberosity to the point of the pin bone; from the external } \\
\text { angle of the ileum to the isquiatic tuberosity }\end{array}$ \\
\hline Longitudinal distance (LD) & From point of the shoulder to the point of the pin bone \\
\hline Shoulder height $(\mathrm{SH})$ & Distance from the surface of a platform to the top of the shoulder \\
\hline Shoulder length (SL) & From the superior border of the scapula to the carpus \\
\hline Snout length (SL) & $\begin{array}{l}\text { Tip of the nasal bone to coronal suture; From the frontal-nasal suture to the point } \\
\text { of the snout }\end{array}$ \\
\hline Tail length (TL) & From insertion of the tail to the tail tip \\
\hline
\end{tabular}

\section{RESULTS AND DISCUSSION}

Sex significantly influenced the morphometric measurements, except for snout length, shoulder length, longitudinal distance and dorso-sternal distance. All morphological traits were influenced by breed, except snout length. The variation coefficient (Table 2) varied between 11.50 and $83.81 \%$, indicating phenotypic variation among individuals. Since different breeds have specific traits such as snout or ear length, these variations are to be expected. The determination coefficient was medium to high varying between 0.06 for snout length to 0.70 tail length. No significant interaction between sex and breed was found, therefore this effect was removed from the model. Sex measurements for morphometric traits (Table 3) such as HL, ED and BL showed significant differences $(\mathrm{P}<0.05)$ between sexes, indicating sexual dimorphism. The heart girth, body length and shoulder height measurements of commercial breeds were higher than most naturalized breeds except for Monteiro and Piau. This is probably due to selection for conformation and meat traits in the commercial breeds, while both naturalized breeds have undergone some artificial selection in the past (Cavalcanti, 2000). 
Table 2 - Summary of variance analysis for body measurements $(\mathrm{cm})$ in swine in South America.

\begin{tabular}{|c|c|c|c|c|c|c|c|c|c|c|c|c|c|}
\hline & LS & $\mathrm{HL}$ & ED & EL & SL & LH & DI & $\mathrm{TL}$ & HG & $\mathrm{BL}$ & SH & LD & $\mathrm{DD}$ \\
\hline ree & NS & *** & **** & $* * *$ & *** & *** & $* * *$ & *** & $* * *$ & *** & $* * *$ & $* * *$ & *** \\
\hline ex & NS & $* *$ & **** & * & NS & ** & $* *$ & $*$ & ** & ** & **** & NS & NS \\
\hline & 0 & 0.3 & 0.6 & & & 0.5 & & & 0. & 0. & 0.55 & 0. & 0.29 \\
\hline & 83.81 & 53 & 5 & 3.96 & 23.30 & $18 .($ & 58 & 35.30 & 12.25 & 12.07 & 6 & 50 & 29.96 \\
\hline lea & 14.96 & 33.80 & 10.78 & 17.47 & 28.25 & 34.25 & 21.17 & 19.66 & 120.33 & 110.70 & 75.31 & 88.40 & 52.95 \\
\hline
\end{tabular}

NS = not significant; $* * * \mathrm{P}<0,001 ; * * \mathrm{P}<0,01 ; * \mathrm{P}<0,05, \mathrm{R}^{2}=$ determination coefficient; $\mathrm{CV}=$ variation coefficient; Snout Length (LS); Head Length (HL); Eye distance (ED); Ear Length (EL); Shoulder Length (SL); Hip length (HL); Distance between isquias (DI); Tail Length (TL); Heart Girth (HG), Body Length (BL); Shoulder Height (SH); Longitudinal distance (LD); Dorsosternal distance (DD).

Table 3 - Corrected means for body measurements in naturalized and commercial pigs from Brazil, Colombia and Uruguay.

\begin{tabular}{|c|c|c|c|c|c|c|c|c|c|c|c|c|c|}
\hline & LS & $\mathrm{HL}$ & ED & EL & SL & $\mathrm{LH}$ & DI & $\mathrm{TL}$ & $\mathrm{HG}$ & $\mathrm{BL}$ & $\mathrm{SH}$ & LD & DD \\
\hline Males & 14.68 & $35.62^{\mathrm{a}}$ & $11.82^{\mathrm{a}}$ & 18.42 & 27.80 & 35.92 & 23.23 & 21.50 & 124.06 & $115.03^{\mathrm{a}}$ & 77.47 & 91.98 & 50.59 \\
\hline Females & 15.08 & $33.09^{\mathrm{b}}$ & $10.40^{\mathrm{b}}$ & 17.11 & 28.44 & 33.61 & 20.39 & 18.99 & 119.19 & $109.36^{\mathrm{b}}$ & 75.63 & 87.39 & 53.62 \\
\hline Bassê & 11.00 & $20.00^{c}$ & $9.04^{\mathrm{c}}$ & $13.00^{c}$ & $16.00^{\mathrm{cd}}$ & $26.00^{\mathrm{bc}}$ & $22.00^{\mathrm{ab}}$ & $22.00^{\mathrm{ab}}$ & $96.00^{\mathrm{d}}$ & $86.00^{\mathrm{e}}$ & $42.00^{\mathrm{e}}$ & - & $52.76^{\mathrm{a}}$ \\
\hline Caruncho & 7.62 & $24.75^{\mathrm{bc}}$ & $9.50^{\mathrm{c}}$ & $12.88^{\mathrm{c}}$ & $13.50^{\mathrm{d}}$ & $29.50^{\mathrm{abc}}$ & $21.25^{\mathrm{ab}}$ & $21.50^{\mathrm{ab}}$ & $100.00^{\mathrm{cd}}$ & $92.00^{\text {de }}$ & $52.38^{\text {cde }}$ & - & - \\
\hline $\begin{array}{l}\text { Casco de } \\
\text { Burro }\end{array}$ & 16.60 & $38.25^{\mathrm{a}}$ & $120^{\mathrm{ab}}$ & $1000^{\mathrm{ab}}$ & 20.10 & $3420^{\mathrm{abc}}$ & 200 & $29.50^{\mathrm{a}}$ & 119. & bcd & abcd & $132.00^{\mathrm{a}}$ & $53.00^{\mathrm{a}}$ \\
\hline $\begin{array}{l}\text { Casco de } \\
\text { Mula }\end{array}$ & 13.64 & $24.55^{\mathrm{bc}}$ & $10.45^{\mathrm{bc}}$ & $16.37^{\mathrm{bc}}$ & $27.28^{\mathrm{abcd}}$ & $28.24^{\mathrm{abc}}$ & - & - & $85.58^{\mathrm{d}}$ & $81.86^{\mathrm{e}}$ & $57.78^{\text {cde }}$ & - & - \\
\hline Duroc & 11.32 & $22.71^{\mathrm{c}}$ & 9.4 & $10.28^{c}$ & $30.82^{\mathrm{abc}}$ & 52.71 & - & - & $132.24^{\mathrm{abc}}$ & $89.52^{\mathrm{de}}$ & $84.20^{\mathrm{a}}$ & - & $41.77^{\mathrm{b}}$ \\
\hline Landrace & 13.57 & $31.53^{\mathrm{ab}}$ & 12.47 & $19.53^{\mathrm{a}}$ & $33.94^{\mathrm{ab}}$ & $44.27^{\mathrm{a}}$ & - & $34.22^{\mathrm{a}}$ & $134.84^{\mathrm{ab}}$ & $106.17^{\text {cde }}$ & $81.65^{\mathrm{a}}$ & - & $33.94^{\mathrm{c}}$ \\
\hline Mamellado & 19.17 & $35.67^{\mathrm{a}}$ & $15.75^{\mathrm{a}}$ & $19.92^{\mathrm{ab}}$ & $34.75^{\mathrm{ab}}$ & $36.33^{\mathrm{abc}}$ & $18.10^{\mathrm{ab}}$ & - & $139.67^{\mathrm{a}}$ & $137.34^{\mathrm{ab}}$ & $80.50^{\mathrm{a}}$ & $102.67^{\mathrm{b}}$ & $48.25^{\mathrm{ab}}$ \\
\hline Monteiro & 13.00 & $33.30^{\mathrm{ab}}$ & $9.48^{\mathrm{c}}$ & $16.00^{\mathrm{bc}}$ & $26.79^{\text {abcd }}$ & $28.00^{\mathrm{abc}}$ & $15.25^{\mathrm{b}}$ & $24.63^{\mathrm{a}}$ & $87.21^{\mathrm{d}}$ & $98.80^{\text {cde }}$ & $63.55^{\text {abcd }}$ & $71.73^{\mathrm{c}}$ & $43.76^{\mathrm{b}}$ \\
\hline Moura & 15.47 & $35.93^{\mathrm{a}}$ & $11.93^{\mathrm{bc}}$ & $20.72^{\mathrm{ab}}$ & $37.58^{\mathrm{a}}$ & $42.72^{\mathrm{a}}$ & $23.34^{\mathrm{ab}}$ & $3.67^{\mathrm{c}}$ & $135.05^{\mathrm{ab}}$ & $151.77^{\mathrm{a}}$ & $79.29^{\mathrm{ab}}$ & $105.85^{\mathrm{ab}}$ & $68.26^{\mathrm{d}}$ \\
\hline Nilo & 10.25 & $28.50^{\mathrm{abc}}$ & $10.01^{\mathrm{bc}}$ & $13.50^{\mathrm{c}}$ & $13.00^{\mathrm{d}}$ & $24.00^{\mathrm{c}}$ & $20.25^{\mathrm{ab}}$ & $5.75^{\mathrm{bc}}$ & $93.00^{\mathrm{d}}$ & $92.00^{\mathrm{de}}$ & $51.13^{\mathrm{de}}$ & - & - \\
\hline Piau & 18.72 & $34.42^{\mathrm{ab}}$ & $10.40^{\mathrm{bc}}$ & $16.63^{\mathrm{bc}}$ & $30.77^{\mathrm{abc}}$ & $39.16^{\mathrm{ab}}$ & $26.92^{\mathrm{ab}}$ & $27.60^{\mathrm{a}}$ & $112.80^{\mathrm{abcd}}$ & $122.37^{\mathrm{abc}}$ & $72.77^{\mathrm{abc}}$ & $91.20^{\mathrm{bc}}$ & $54.05^{\mathrm{a}}$ \\
\hline $\begin{array}{l}\text { Rabo de } \\
\text { Peixe }\end{array}$ & 12.00 & $32.00^{\mathrm{ab}}$ & $9.67^{\mathrm{c}}$ & $17.34^{\mathrm{bc}}$ & $14.67^{\mathrm{d}}$ & $27.50^{\mathrm{bc}}$ & $23.00^{\mathrm{ab}}$ & $6.00^{\mathrm{bc}}$ & $102.67^{\mathrm{bcd}}$ & $84.01^{\mathrm{e}}$ & $59.00^{\text {bcde }}$ & - & - \\
\hline Sanpedreño & 10.09 & $24.22^{\mathrm{bc}}$ & $10.52^{\mathrm{bc}}$ & $16.14^{\mathrm{bc}}$ & $26.24^{\mathrm{abcd}}$ & $27.35^{\mathrm{abc}}$ & - & - & $128.49^{\mathrm{ab}}$ & $70.65^{f}$ & $76.28^{\mathrm{a}}$ & & - \\
\hline Tatu & 14.50 & $34.50^{\mathrm{ab}}$ & $13.00^{\mathrm{ab}}$ & $25.00^{\mathrm{a}}$ & $15.00^{\mathrm{cd}}$ & $36.50^{\mathrm{abc}}$ & $22.50^{\mathrm{ab}}$ & $33.00^{\mathrm{a}}$ & $98.75^{\mathrm{d}}$ & $116.50^{\mathrm{bcd}}$ & $68.50^{\mathrm{abcd}}$ & - & - \\
\hline Yorkshire & 16.14 & $35.51^{\mathrm{a}}$ & $14.21^{\mathrm{a}}$ & $24.21^{\mathrm{a}}$ & $39.27^{\mathrm{a}}$ & $52.81^{\mathrm{a}}$ & - & $30.18^{\mathrm{a}}$ & $135.59^{\mathrm{ab}}$ & $113.18^{\text {bcde }}$ & $83.63^{\mathrm{a}}$ & - & $40.35^{\mathrm{b}}$ \\
\hline Zungo & 14.71 & $29.45^{\mathrm{abc}}$ & $11.45^{\mathrm{bc}}$ & $20.60^{\mathrm{ab}}$ & $20.60^{\text {bcd }}$ & $28.72^{\mathrm{abc}}$ & - & - & $100.33^{\text {cd }}$ & $67.73^{\mathrm{f}}$ & $68.26^{\mathrm{abcd}}$ & - & - \\
\hline
\end{tabular}

${ }_{a, b, c, d, e}$ Means followed by different letters within the same column differ $(\mathrm{P}<0,05)$ by Tukey Test. Snout Length (LS); Head Length (HL); Eye distance (ED); Ear Length (EL); Shoulder Length (SL); Hip length (LH); Distance between isquias (DI); Tail Length (TL); Heart Girth (HG), Body Length (BL); Shoulder Height (SH); Longitudinal distance (LD); Dorso-sternal distance (DD).

The Uruguayan breed Mamellado was as large as the commercial breeds for hearth girth and shoulder height and larger than the mean for other traits. Casco de Burro, Moura and Piau were also shown to be large naturalized breeds. The Moura breed was the naturalized Brazilian breed which was closest in shoulder height to the commercial breeds, followed by the Piau. These measurements for the two breeds in question were not significantly different $(\mathrm{P}>0.05)$. Their genetic proximity would need to be confirmed by molecular studies. This was probably due to the type of breeding undergone by each of these breeds. While Moura animals were generally found in rustic settings, Monteiro were reared extensively (almost feral) in the Pantanal region of Mato Grosso State. Correlations between snout, ear and head length and eye distance were low to medium (Table 4). Most size measurements were high, with the largest between thoracic perimeter and body length (0.87). These are in agreement with those found by Miserani et al. (2002) and McManus et al. (2005) studying commercial and naturalized horse breeds and Oliveira et al. (2006) 
studying naturalized cattle breeds. These differences are probably due to the fact that head traits are strongly related to breed while body traits are strongly influenced by the environment, depending on feeding regime and rearing system.

Table 4 - Correlations between body measurements in naturalized pigs in Brazil, Uruguay and Colombia.

\begin{tabular}{lcccccccccccc}
\hline & LS & HL & ED & EL & TL & HG & BL & SH & LD & DD & SL & LH \\
\hline HL & 0.23 &. &. &. &. &. &. &. &. &. &. &. \\
ED & -0.13 & 0.39 &. &. &. &. &. &. &. &. &. &. \\
EL & 0.09 & 0.46 & 0.53 &. &. &. &. &. &. &. &. &. \\
TL & 0.11 & 0.51 & 0.39 & 0.47 &. &. &. &. &. &. &. &. \\
HG & 0.19 & 0.44 & 0.50 & 0.53 & 0.30 &. &. &. &. &. &. &. \\
BL & 0.25 & 0.51 & 0.54 & 0.61 & 0.56 & 0.87 &. &. &. &. &. &. \\
SH & 0.22 & 0.67 & 0.48 & 0.59 & 0.51 & 0.77 & 0.83 &. &. &. &. &. \\
LD & 0.17 & 0.25 & 0.53 & 0.53 & 0.45 & 0.83 & 0.83 & 0.72 &. &. &. &. \\
DD & 0.07 & 0.13 & 0.29 & 0.46 & 0.09 & 0.66 & 0.64 & 0.56 & 0.60 &. &. &. \\
SL & 0.25 & 0.44 & 0.18 & 0.33 & 0.30 & 0.60 & 0.72 & 0.76 & 0.71 & 0.47 &. &. \\
LH & 0.19 & 0.45 & 0.47 & 0.50 & 0.37 & 0.86 & 0.87 & 0.78 & 0.79 & 0.66 & 0.65 & \\
DI & 0.17 & 0.41 & 0.51 & 0.40 & 0.30 & 0.74 & 0.61 & 0.54 & 0.73 & 0.60 & 0.17 & 0.67 \\
\hline
\end{tabular}

Snout Length (LS); Head Length (HL); Eye distance (ED); Ear Length (EL); Shoulder Length (SL); Hip length (LH); Distance between isquias (DI); Tail Length (TL); Heart Girth (HG), Body Length (BL); Shoulder Height (SH); Longitudinal distance (LD); Dorso-sternal distance (DD); Rib Width (BD).

The first two autovectors (Fig. 1) explained $49 \%$ of all variation between the traits measured. The first showed that an animal large for one trait was generally large for all, except dorso-sternal distance, in accordance with studies in other species (Miserani et al., 2002; McManus et al., 2005). The second described a sub group of animals with wide hips and small thoracic perimeter. The naturalized Brazilian Caruncho breed and commercial Landrace were seen to be further apart (Figs. 2 and 3) for male and female adults respectively. The Caruncho is a small, dark skinned, very rustic, lard type animal while the Landrace is a white skinned, long meat producing animal (Cavalvanti, 2000).

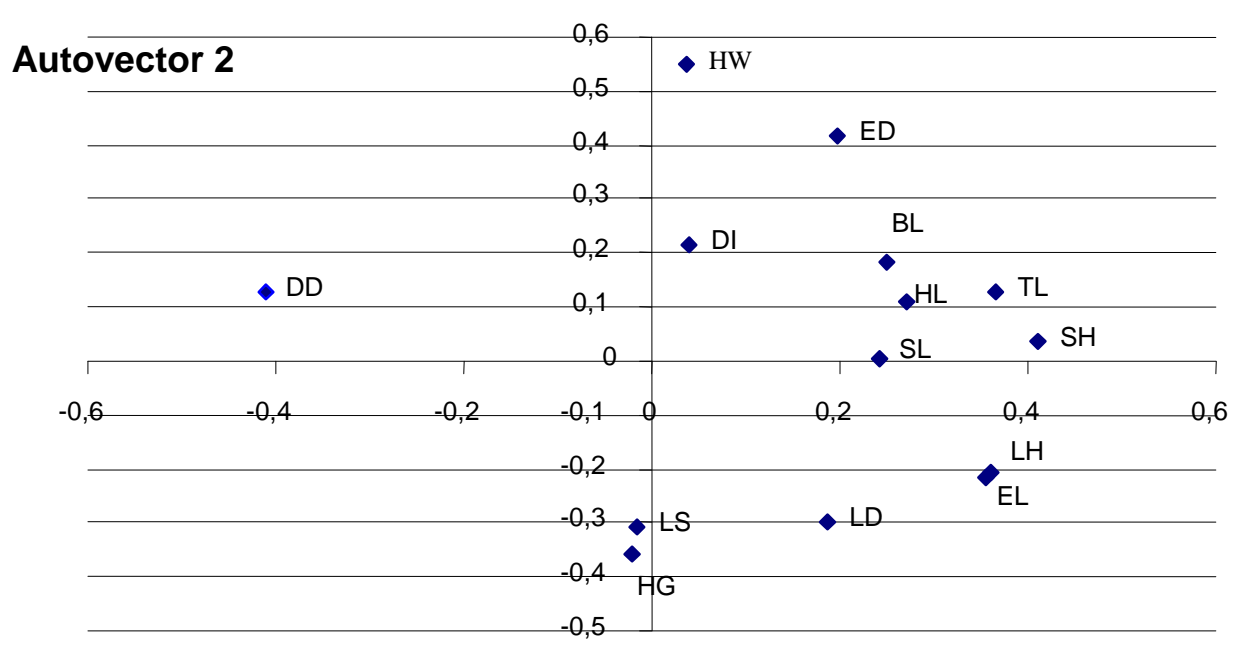

\section{Autovector 1}

Figure 1 - Autovectors traits of commercial and naturalized pig size from Brazil, Uruguay e Colombia. Snout Length (LS); Head Length (HL); Eye distance (ED); Ear Length (EL); Shoulder Length (SL); Hip length (LH); Hip width (HW), Distance between isquias (DI); Tail Length (TL); Heart Girth (HG), Body Length (BL); Shoulder Height (SH); Longitudinal distance (LD); Dorso-sternal distance (DD); Rib Width (BD). 
Figure 2 (adult males) showed that large bodied animals were separated from small bodied ones, forming two groups. Although the Mamellado breed had some high morphometric measures such as thoracic perimeter and body length, this breed was classified in the smaller group according with dendogram, as most parameters grouped this breed with the smaller breeds. Comparing Figures 2 and 3 , the latter (females) showed better group definition for breeds. This may be explained by the fact that more females were sampled than males. Figure 3 showed three principal groups of swine. The first of small naturalized breeds, second large naturalized breeds and the third large commercial animals. In the second group, the Moura and Piau breeds were closely related, in agreement with that found in Table 2.

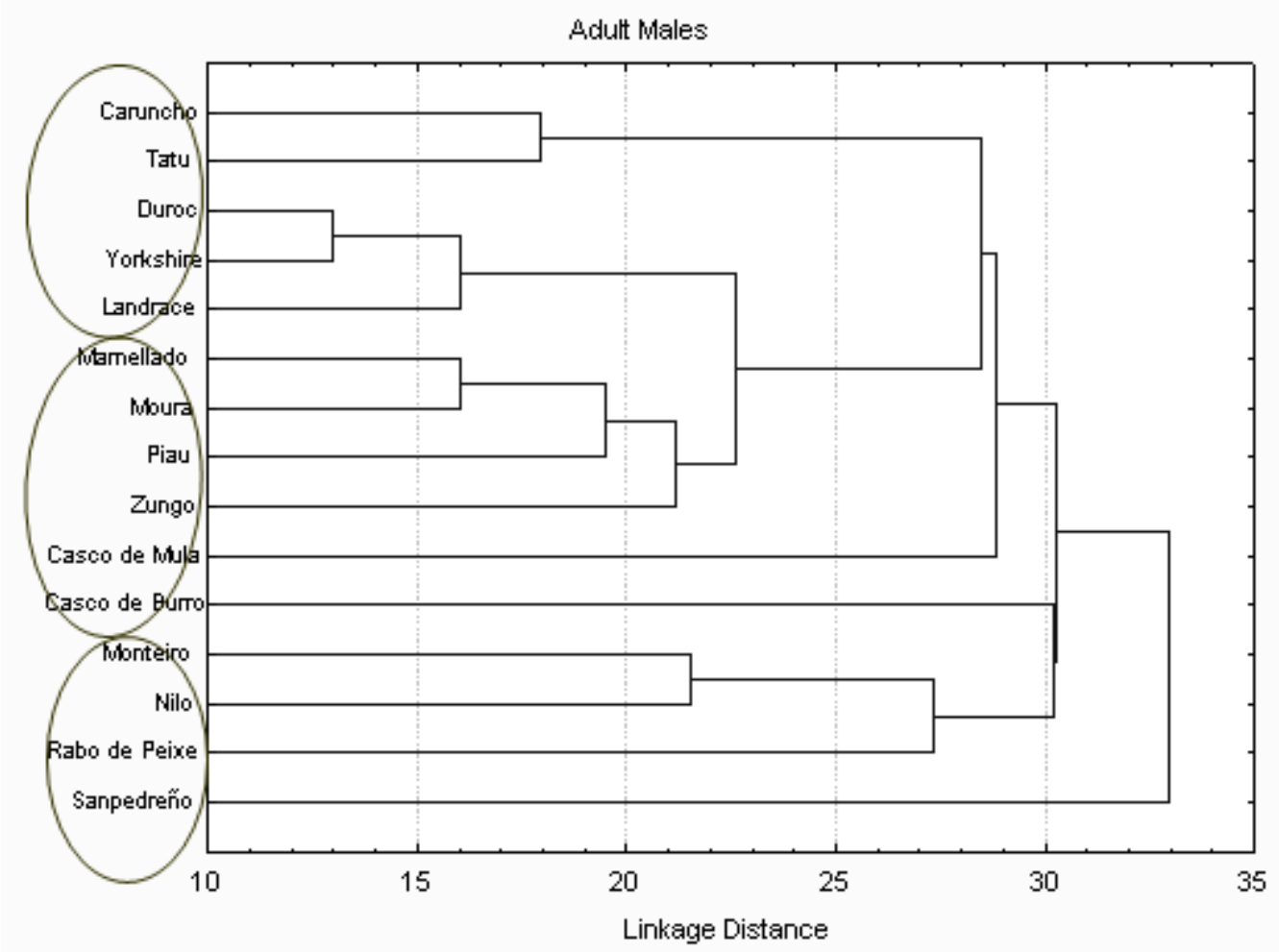

Figure 2 - Dendogram UPGMA based on distances between adult swine breeds using morphometric measures.

Figure 4 shows the division of breeds due to morphological traits. Three main groups were separated. The naturalized Brazilian breeds in the first group, which included the Bassê, Nilo and Tatu breeds, all have dark skin, lack hair and have a pendulous abdomen, characteristic of lard producers (Cavalcanti, 2000). The Marmellado (Uruguayan breed) was classified together with the commercial breeds, maybe indicating more recent crossbreeding, while the Zungo (Colombian breed) was closer to the larger naturalized Brazilian breeds. The commercial breeds (Duroc, Landrace, Large White, Yorkshire) were all selected for meat production while the Casco de Burro and Mamellado showed common traits such as straight abdomen line, more typical of meat breeds. The latter is also a large animal and possibly was descended from the Spanish and Portuguese Iberian breeds as well as breeds from the Mediterranean trunk (Bermejo, 2004). The closeness of the Duroc to the naturalized breeds may be due to its origin as a lard type pig, but through generations of selection it became widely used as a meat breed. Comparison of this analysis with that of molecular distances based on microsatellite data (Sollero, 2006) confirms the origin of these breeds, showing that this type of analysis may be a useful tool for defining breeds and distances between them in the absence of molecular techniques. 


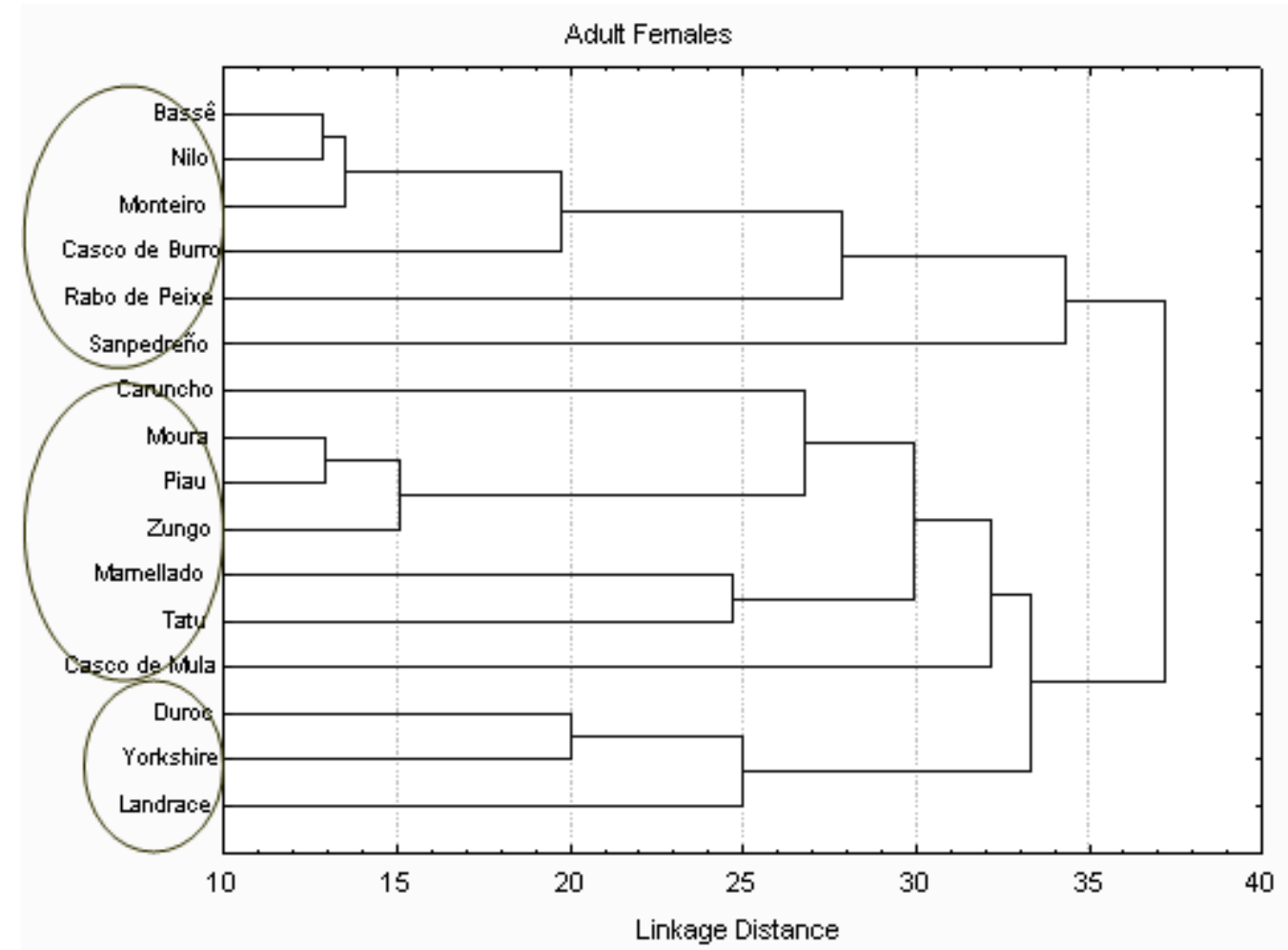

Figure 3 - Dendrogram UPGMA based on distances between adult female swine using morphological measurements.

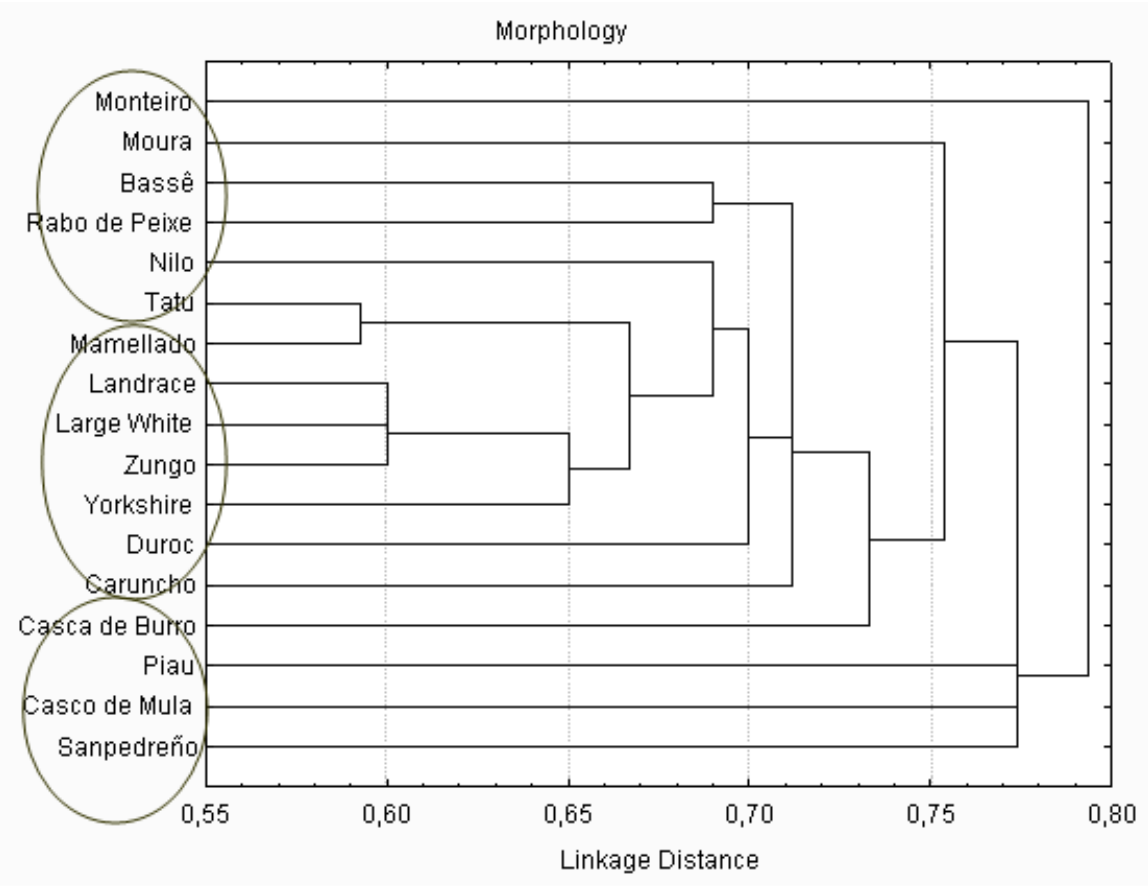

Figure 4 - Dendogram UPGMA based on distances between naturalized and commercial swine breeds using morphological data. 


\section{CONCLUSION}

Morphometric and morphology analyses may be useful in breed comparisons. These results were comparable to those from genetic marker studies. Breed distances varied depending on the data used but in general three groups were identified, small naturalized breeds, large naturalized breeds and commercial breeds. Much data is still lacking for naturalized breeds.

\section{ACKNOWLEDGEMENTS}

The authors wish to thank CNPq for scholarships and financial aid (Prosul), including INCT-IGSPB, as well as the farmers and researchers who contributed with data and access to the animals.

\section{RESUMO}

Foram colhidos dados morfométricos de 859 suínos naturalizados do Brasil (Piau, Tatu, Nilo, Caruncho, Casco de Burro, Moura, Monteiro e Rabo de Peixe), Colômbia (Criolla Zungo, Sanpedreño e Casco de Mula) e Uruguai (Mamellado) Dados sobre raça, sexo e idade foram coletados, assim como varias avaliações morfométricas. A análise de variância foi realizada utilizando-se o procedimento PROC GLM do SAS sobre os dados morfométricos. Os coeficientes de variância oscilaram de 11,50 a $83,81 \%$ e o coeficiente de determinação foi de moderado a alto. As fêmeas foram em geral menores na maioria das avaliações em relação aos machos, indicando dimorfismo sexual. A Moura foi a raça naturalizada mais próxima das raças comerciais, seguida da Piau, enquanto a Monteiro apresentouse mais distante. $\mathrm{O}$ dendograma obtido a partir de informações morfológicas apresentou divisão dentro de três grupos. A caracterização foi possível utilizando-se dados morfológicos e morfométricos.

\section{REFERENCES}

Anil, L., Anil, S.S., Deen, J. (2002) Evaluation of the relationship between injuries and size of gestation stalls relative to size of sows. 221:834-836
Bermejo, J.V.D. (2004), Biodiversidad Porcina Iberoamericana: Caracterización y uso sustentable. 1. ed. Córdoba, 329p.

Cavalcanti, S.S. (2000), Suinocultura Dinâmica. 2. ed. Contagem: FEP - MVZ Editora, 494p.

Egito, A.A; Mariante A.S.; Albuquerque M.S.M. (2002), Programa Brasileiro de Conservação de Recursos Genéticos Animais. Arch. de Zootecnia. Córdoba. 51, 39-52.

FAO (1999), Primary Guidelines for Development of Nation Farm Animal Genetic Resource Management Plants. http://www.fao.org/dad-is. Acessed in 2004/03/12.

Garcia, S.K.; Barbosa, A.S. (2005), Conservação $e$ Estudo de raças suínas brasileiras na UFMG - 12 anos. Escola de Veterinária. Belo Horizonte, pp 295297.

Gonyou, H.W, Stricklin, W.R. (1998), Effects of floor area allowance and group size on the productivity of growing/finishing pigs, J. Anim. Sci. 76, 1326-1330.

Lawrence, T.L., Fowler, V.R. (1997), Growth of Farm Animals. CAB International, Wallingford, Oxon, UK, p. 330

Mariante A.S.; Cavalacante, N. (2000) Animais do Descobrimento: Raças domésticas da história do Brasil. Embrapa Recursos Genéticos e Biotecnologia. $1^{\mathrm{a}}$ Ed. Brasília - DF. 2000.

Mariante A.S.; Egito, A.A. (2002), Animal Genetic Resources in Brazil: result of five centuries of natural selection. Theriogenology, 233-235. 2002.

McManus, C.M.; Falcão, R.A.; Spritze, A.; Costa, D.; Louvandini, H.; Dias, L.T.; Teixeira, R.A.; Rezende, M.J.M.; Garcia, J.A.S. (2005), Caracterização morfológica de Eqüinos da Raça Campeiro. Rev. Bras. de Zootecnia, 34, 1553-1562.

Miserani, M.; McManus, C.M.; Mariante A.S.; Abreu, U.G.P.; Santos, S.A.; Silva, J. (2002), Variance analyses for biometric measures of the Pantaneiro horse in Brazil. Arch. de Zootecnia, Córdoba, 51, 113-121.

Notter, D.R. (1998), The importance of genetic diversity in livestock populations of the future. $J$. Anim. Sci. 77, 61-69.

Oliveira, E.M.B.; McManus, C.M.; Lucci, C.M.; Fernandes, M.C.B.; Prescott, E.; Mariante A.S.; Egito, A.A. (2006), Características corporais associadas com adaptação ao calor em bovinos naturalizados Brasileiros. Pesquisa Agropecuária Brasileira, 41, 1443-1448.

Pastorelli, G., Musella, M., Zaninelli, M., Tangorra, F., Corino, C. (2006) Static spatial requirements of growing-finishing and heavy pigs. Livestock Science 105, 260-264.

Pietrolà E., Pilla, F., Maiorano, G., Matassino, D. (2006). Morphological traits, reproductive and productive performances of Casertana pigs reared outdoors. J. Anim. Sci. 5:139-146. 
Rothschild, M.F. (2003), Approaches and Challenges in Measuring Genetic Diversity in Pig. Arch. Zoot., 52, 129-135.

SAS - Statistical Analyses System, (1999). User's guide: Statistics. Version 8 (TS MO). Cary.

Sollero, B.P. (2006), Diversidade Genética das Raças Naturalizadas de Suínos no Brasil por meio de Marcadores Microssatélites. Brasília, 87p. Dissertação (Mestrado)-Faculdade de Agronomia e Medicina Veterinária, Universidade de Brasília.
Spoolder, H.A.M., Edwards, S.A.; Corning. S. (2000). Legislative methods for specifying stocking density and consequences forthe welfare of finishing pigs. Livest. Prod. Sci. 64,167-173.

Received: October 08, 2007; Revised: April 16, 2008; Accepted: July 02, 2009. 